This is an electronic reprint of the original article. This reprint may differ from the original in pagination and typographic detail.

Author(s): Lähdesmäki, Tuuli

Title: $\quad$ Pop-Up Architecture as Urban Regeneration

Year: $\quad 2016$

Version:

Please cite the original version:

Lähdesmäki, T. (2016). Pop-Up Architecture as Urban Regeneration. In J. Jordaan, C. Haddrell, \& C. Alegria (Eds.), Dialectics of Space and Place across Virtual and Corporeal Topographies (pp. 263-274). Inter-Disciplinary Press. https://doi.org/10.1163/9781848885103_024

All material supplied via JYX is protected by copyright and other intellectual property rights, and duplication or sale of all or part of any of the repository collections is not permitted, except that material may be duplicated by you for your research use or educational purposes in electronic or print form. You must obtain permission for any other use. Electronic or print copies may not be offered, whether for sale or otherwise to anyone who is not an authorised user. 


\title{
Pop-up Architecture as Urban Regeneration
}

\author{
Tuuli Lähdesmäki
}

\begin{abstract}
Recent ideas in urban planning, conceptualized e.g., as New Urbanism, emphasize the humane point of view of the city. The focus of these ideas is on the citizens and their experiences of feeling comfortable and at home in the urban space; people's possibilities of spending leisure time in the city centre; and enabling the encounter of different people in the city space in order to bring the inner city to life. To revitalize the less used, unused, or decayed city spaces by using them as venues for diverse cultural activities is a part of these ideas. The means of urban regeneration often rely on ambitious and permanent transformations of the urban space, such as constructing cultural infrastructure and spectacular buildings for cultural or leisure use. However, one of the frequently used methods of urban regeneration today is the use of temporary architectural intervention into the city space: setting up nonpermanent structures, constructions, or buildings for cultural or leisure use. This kind of 'pop-up architecture' may even be regarded as a category of 'new genre public art', because of its artistic, social, and communal emphases. One of the EU's urban initiatives - the annual designation of the European Capital of Culture (ECOC) - encourages European cities to promote various forms of urban regeneration as a part of city development. The limited length of the designation (one year) has led the designated cities to implement and host various temporary architectural projects in which the city space is intervened through various tactics and to reach diverse goals. In the paper, I will investigate the goals and tactics of temporary architectural projects in the recent ECOCs, and discuss how the architectural intervention in the urban space is aimed to work as a means of urban regeneration. The theoretical framework of the paper relies on discussions in the fields of cultural policy research, urban studies, and visual culture studies.
\end{abstract}

Key Words: architecture, economy, the European Capital of Culture, temporality, urban regeneration, urban space.

$* * * * *$

\section{Introduction: The Role of Architecture in the Urban Regeneration}

The emphasis on economic and cultural development and the interconnection between the spheres of culture and economy characterizes the current cultural policy discourses in the Western world. ${ }^{1}$ The spheres of culture and economy form an inter-discursive domain, in which culture has been transformed into an economic keyword. ${ }^{2}$ The concepts of creative economy and cultural economy which are often referred to in the cultural policy discourses and urban development and management talk - are based on the idea of a correlation between cultural and 
economic development: strengthening one of them is considered to advance the other. In addition, the economic dimension of culture has often been intertwined with urbanity - cities have been considered as drivers of economic growth, and the urban space as a factor supporting that function. ${ }^{3}$ Thus, in the cultural policy discourses and urban development and management talk, the ideas of urban space, culture, creativity, and economy form an interrelated and inter-determined sphere of meanings.

During recent decades, decision-makers and urban planners have aimed to advance the economic growth of Western cities by promoting diverse cultural projects and the development of the city space. These aims have been discussed and conceptualized within academia using the concepts of urban revitalization and urban regeneration. The concepts are often used interchangeably, but some scholars, such as Robert Cowan, have distinguished between them by explaining urban regeneration as referring mainly to physical change and improvements of the environment, while revitalization is considered to signify social improvements and other ways - such as cultural ones - of bringing a place to life. ${ }^{4}$ However, culture may have a crucial role in the physical transformation and development processes of the urban space. Thus some scholars, such as Graeme Evans, have distinguished different modes of urban regeneration on the basis of the role of culture in it. For example, in 'culture-led' regeneration cultural activity functions as a catalyst and an engine of regeneration, while in 'cultural regeneration' cultural activity is integrated into an area strategy alongside other activities in the environmental, social, and economic spheres. ${ }^{5}$

On one hand, decision-makers and urban planners seem to believe that the physical transformation of the urban space is necessary in order to bring about urban development and stimulate economic growth. ${ }^{6}$ On the other hand, during the past couple of decades culture-driven regeneration has occupied a pivotal position in contemporary urban policies. ${ }^{7}$ The combined aims of the physical transformation of the urban space and the various cultural interventions to it form a common strategy in today's urban planning.

A commonly used and concrete means for cultural regeneration in contemporary cities is architecture. During the past couple of decades, several cities have aimed to tackle the problem of their declining industries and economic regression by investing in major cultural institutions, such as cultural centres, art museums, or opera houses, and constructing for these institutions unique buildings aimed to function as global landmarks. World-famous architects have been invited to plan outstanding and spectacular buildings in order to attract visitors and cultural operators, raise media attention, transform the city image, draw new investments to the city, etc. This kind of cultural regeneration strategy is extremely risky due to its massive scale and major expenses. The so-called 'wow-architecture' and cultural infrastructure-based projects are also relatively inflexible strategies of cultural regeneration and image-making. ${ }^{8}$ In addition, concrete results of this kind of 'hard 
branding' of a city - based on the reputation and signature of global architects and its impacts on the regeneration objectives may be difficult to prove. ${ }^{9}$

In academia the role of architecture in cultural regeneration has often been discussed in relation to 'wow-architecture' and building new cultural infrastructure for major cultural institutions. Are there other ways architecture is used in the contemporary cultural regeneration? One of the often used means in cultural regeneration today is the use of temporary architectural intervention into the city space: setting up non-permanent structures, constructions, or buildings for cultural or leisure use. Besides urban planners and local authorities responsible for city development, many civil associations also aim to revitalize urban space through event-orientated temporary architectural projects. ${ }^{10}$ Sometimes the forms of this kind of 'pop-up architecture' can be placed in the category of urban art, community art, or 'new genre public art', a term coined by Susanne Lacy ${ }^{11}$, because of their artistic and communal emphases and practices involving direct social engagement. In addition, the communal and social emphasis of the recent temporary architectural projects relates them to the tradition of activist architectural practices that Nishat Awan, Tatjana Schneider, and Jeremy Till have termed 'spatial agency, ${ }^{12}$

In the paper, I will investigate the goals and tactics of temporary architectural projects in three case cities, and discuss how the temporary architectural intervention in the urban space is aimed to work as a means of cultural regeneration. The data of the paper consists of the planning and promotional materials of these case projects, their observation, and discussions of them with local people and cultural operators during field research and visits to the case cities. The theoretical framework of the paper relies on discussions in the fields of cultural policy research, urban studies, and visual culture studies.

\section{The European Capital of Culture Designation as an Instrument for Cultural Regeneration}

Urban regeneration is an important political instrument through which decisionmakers and authorities at local, regional, and national levels aim to govern diverse economic and social issues. During the past couple of decades, the EU has been interested in urban development as a tool to influence European cities. One of the EU's most successful urban initiatives - the annual designation of the European Capital of Culture (ECOC) - encourages European cities to promote cultural regeneration as a part of the city development. During the 28 years of its history, the ECOC initiative has developed from a short-term high-cultural festival to a year-long urban event which enables manifold economic and social developments and a regeneration of the city space. Various ECOCs have used the initiative as a tool to revive the city and develop its urban space by constructing new buildings and renovating old estates for cultural and leisure use. In spite of the detailed plans, many of the large-scale construction and renovation projects in the ECOCs have 
not been implemented or finished as planned due to increased expenses, financing problems, and the lack of investors. The limited budgets and the short length of the designation have led many of the ECOCs to implement and host various small scale architectural projects that influence the urban space only temporarily. Many of these projects aim to achieve the 'wow-effect' of the spectacular architecture but on a smaller scale and with much smaller expenses. On the one hand, the temporary nature and the small scale produce challenges for the planning and implementation of architectural projects. On the other hand, they create possibilities for a new kind of experimentality and innovativeness regarding the material, form, location, and function of the constructions.

In order to maximize the attention value of the ECOC designation, several designated cities have aimed to produce new and exceptional spatial attractions to the city - particularly during the tourist season - in order to attract visitors, increase the interest of the local citizens in their home city and its urban space, raise media attention, and have a positive influence on the city image. These new spatial attractions have often been set up only for a couple of months and in unexpected and surprising locations in the city centre. Thus these projects can be described as architectural interventions following the 'pop-up' ideology currently common in Western urban culture. As pop-up restaurants and galleries, etc., the pop-up architectural projects have activated local citizens to experience and use the urban space in a new way, brought people into less or unused urban spaces, and enabled the encountering of different people and groups within the urban space.

\section{Pop-up Architectural Projects in Tallinn, Turku, and Maribor}

The cultural programs in the recently designated ECOCs include several popup architectural projects of which I have chosen three for closer inspection. The selection of the cases is based on the differences in their regeneration objectives and the concrete tactics of influencing the urban space and its uses and users. However, the cases have much in common: in all of them the architectural intervention brought to the urban space for a couple of months some exceptional structures which changed the meanings of urban space, transformed its former uses, and created visual dialogue between the elements of the space.

Tallinn, the capital of Estonia, was designated as the ECOC for 2011. The biggest cultural project in the city, especially created for the ECOC year, was the Straw Theatre - a temporary theatre building in which the Estonian Theatre NO99 and other artists performed their plays, concerts, and works of art from May to September. The building, designed by Salto Architects (Maarja Kask, Karli Luik, Ralf Lõoke, and Pelle-Sten Viiburg), was constructed of a wooden frame using uncovered straw bales which were spray-painted black. The theatre was located next to the Old Town on the Skoone Bastion - a neglected and decayed site that had a wooden navy theatre and a park during the Soviet occupation. After the Soviet troops left the country and the old theatre burnt down, the bastion remained a closed and abandoned site which was not taken into any real-estate or recreation 
use although various urban development plans were drafted during the past two decades. The temporary building offered a possibility to reactivate the unused location and test its potential for cultural and leisure use. It did not leave any permanent marks on the site, and respected its historical layers e.g., by utilizing the remaining stone bases and staircases of the earlier navy theatre.

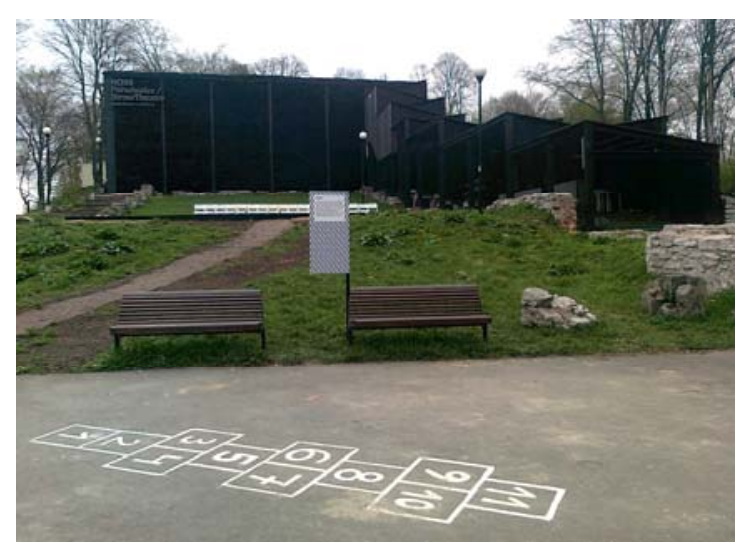

Image 1: Straw Theatre, designed by Salto Architects, in Tallinn, Estonia, in May 2011. Photo: Tuuli Lähdesmäki.

The surroundings of the Straw Theatre were transformed into an open 'living room' for the local citizens and visitors. The area in front of the theatre was covered by a lawn and a wooden terrace. It included a sandpit, a hopscotch court, a grill, a snack bar, and a space for the visitors to read cultural magazines.

The Straw Theatre succeeded in drawing local citizens from all age groups, including families, to spend time in the recreated area. The performances in the theatre attracted a lot of visitors and its program was considered as international, topical, and high quality. The project succeeded to turn the decayed site into an urban experiment in which a 'non-place' close to the city centre could be experienced in a new way and given new meanings. The spectacular look and the ecological and experimental - but at the same time profoundly traditional material of the building raised a lot of interest in the media and among the local citizens and tourists. The 'wow-effect' of the architecture brought a lot of people to the site just to be amazed by the building. After five months the theatre was taken down and the site returned to its previous state.

Turku, a city in the South-West Finland, was designed as the ECOC for 2011 together with Tallinn. The major architectural project in the cultural program of Turku in 2011 was the Sauna Lab. In the project four Finnish artists (Jan-Erik Anderson, Heidi Lunabba, Harri Markkula, and Hans-Christian Berg) were invited 
to design site-specific artistic saunas, which were located in different sites in the city centre and nearby districts for the summer months. Saunas are a profoundly traditional yet a living part of the Finnish culture. However, the long tradition of public saunas is diminishing. The aim of the Sauna Lab was to bring together traditional Finnish culture and an innovative contemporary design, blur the ideas of an intimate space and public space, revitalize the tradition of urban public saunas, and bring new communal elements to the urban space. The saunas were in public use and could be reserved for groups from June to August.

All the saunas relied on unique forms and artistic elements in their design. Anderson's Sounding Dome Sauna was made of fibreglass and was from the outside reminiscent of giant yellow garlic. Inside the sauna, the bathers could listen to the work of the sound artist Shawn Decker. The sauna was located in a local open air swimming arena. Lunabba's Sauna Obscura floated on a raft in the sea near a public beach. The sauna was based on the idea of a camera obscura: the surrounding environment of the Turku Archipelago was projected upside down to the walls of the sauna and the skins of the bathers blurring the border between the inside and the outside turning the sauna into a kind of a live movie theatre. Markkula's Hot Cube was located in the city centre above the Aura River, which crosses the city. The sauna was made using tarred wooden panels which formed a windowless cube. The river could be seen through lattices in the sauna floor. Breg's Solaris, designed in co-operation with the industrial designer Mika Ihanus, was a transparent round glass building located on a small hill next to one of the city's art museums, a busy road, and a bridge crossing the Aura River.

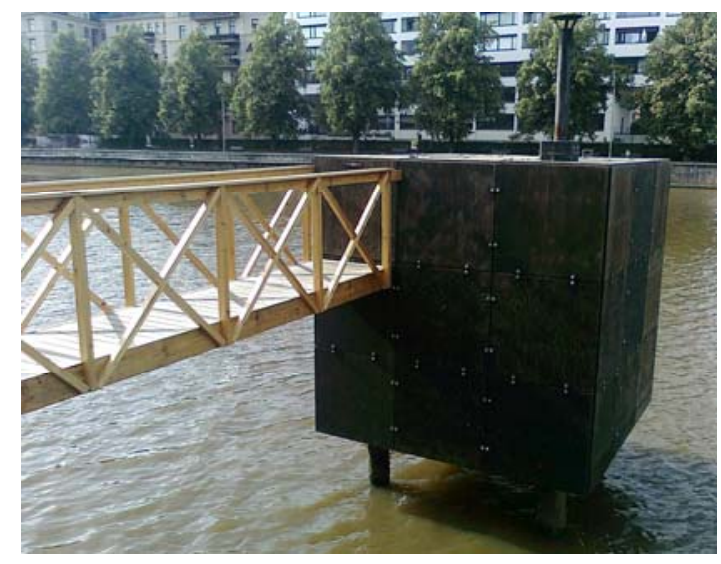

Image 2: Temporary sauna Hot Cube, designed by Harri Markkula, in Turku, Finland, in August 2011. Photo: Tuuli Lähdesmäki. 
The Sauna Lab brought unexpected functions into the urban space by offering the possibility of bathing and relaxation in the urban space, and meeting other citizens and cultural tourists within an intimate space. The artistic design of the saunas raised a lot of interest in the media and among citizens and tourists. According to the bathers, bathing in an artistically unique sauna in an unexpected place in the city was experienced as extraordinary and unforgettable. In September the saunas were removed.

Maribor, a city in Northern Slovenia, was designated as one of the ECOCs for 2012. During the year, one of the main squares in the city - the Trg Svobode functioned as the location of a temporary exhibition space called the White Noise pavilion. It was designed by Austrian architecture collective Soma (Johan Tali, Alex Matl, and Karin Dobbler), which had in 2011 won an open architectural competition held by the Salzburg Regional Government aiming to promote contemporary architecture and architectural interventions in public space. The pavilion was constructed of 1500 aluminium bars, which were connected following a set of rules and variations in order to form an organic sculpture-like structure. The aluminium structure of the pavilion was lined with a tarp. After the win, the architects toured different cities with the pavilion. Maribor bought it for six weeks as a part of the city's ECOC program. From September to October the pavilion hosted diverse small concerts, exhibitions, discussions, and screenings in the city. The look of the pavilion was extraordinary and eye-catching forming a strong contrast with historical buildings surrounding the square. It also brought new cultural uses to the square which, for example, is the location of a bronze monument for the National Liberation War and is used for fairs and as a market place.

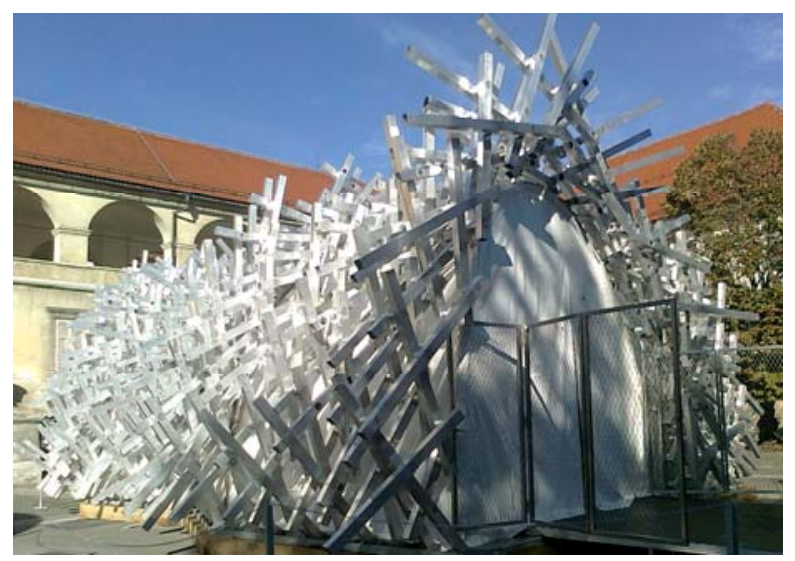

Image 3: The White Noise pavilion, designed by Soma collective, in Maribor, Slovenia, in October 2012. Photo: Tuuli Lähdesmäki. 
The White Noise pavilion is an example of an international, temporary, and movable artistic and architectural project which can be bought for a limited period of time for the urban space in order to bring it to life and activate the cultural and communal participation of the citizens. Similar kinds of 'touring' projects have been utilized by several recent ECOCs as a part of their cultural programs. ${ }^{13}$

\section{Contextualizing the Pop-up Architecture}

The current interest in regenerating urban space by setting-up temporary buildings reflects the recent ideas and aims of urban planning. The focus of these ideas and aims is in increasing the interaction and communication between citizens in the urban space, strengthening communality and urban identities in the city, rediscovering the city centre and its activities, and fostering human-scale and pedestrian-friendly urban design as a basis for 'livable' cities. Scholars have discussed and conceptualized these theories and practices of urban planning by relating them to a communicative paradigm in urban planning ${ }^{14}$, post-modern planning principles ${ }^{15}$, and a set of planning ideas termed as New Urbanism ${ }^{16}$.

The recent ideas of urban planning intertwine with the economic and social motives described in the first chapter. Besides cultural and creative economy, the current aims of urban planning reflect the ideas brought together in the concept of experience economy. Some scholars have described these ideas as an 'economy of fascination' in order to emphasize how cities have been competitively themed to market their unique 'experience world'. ${ }^{17}$ During the past three decades, politicians, planners, and marketing experts have increasingly focused on the development of experiences in order to foster consumption. ${ }^{18}$ As a consequence, cities have started to seek possibilities to offer people spectacular urban environments, designed for these moments of extraordinary experiences, in order to profit from their interest to gain new experiences. ${ }^{19}$ The experience-based urban planning has moved from investing in 'hard' location factors, such as roads and major buildings, towards 'soft' location factors, such as recreational activities and place-based installations. Aestheticization of urban space is at the same time one of the means and outcomes of the experienced-based ideas of planning. On the one hand, aestheticization is a process that aims to create novelty, surprise, and excitement, but on the other hand, it may only result in superficial changes. ${ }^{20}$

The attempts to enliven the city centres and make the cities more 'livable' often originate from a top-down decision-making and urban planning practices. Scholars have criticized these practices for forgetting to involve local people and ordinary citizens in the urban planning and regeneration processes. ${ }^{21}$ In fact, the recent trends in urban regeneration emphasize, in particular, the role of local communities in both the planning and implementation of regeneration projects. As a consequence, community regeneration has become an integral part of urban regeneration. Today, the success of urban regeneration projects is not only measured in the physical transformation of the city space or its economic impact 
but also in its outcomes in creating vibrant communities, interaction between the citizens, feeling of comfort in the urban space, active participation with cultural and social issues, and interests in the urban environment.

The examples from the recent ECOCs indicate that temporary architectural projects can revitalize, regenerate, and produce new meanings for the urban space, activate people to use the public spaces in a new way, increase social interaction in the city, and raise positive public attention. Temporary architectural projects are easy, fast, cheap, and less risky modes of creating 'wow-effects' within the urban space - an outcome the urban planners often long for - than the large-scale wowarchitecture. On one hand, the cultural, social, and economic impacts of the temporary projects may be short-term and limited in scale. On the other hand, the temporary nature respects the existing structures and historical layers of the city without aiming to change the urban space permanently. This temporary nature enables the implementation of innovative architectural and communal experiments, playing with the experiential and affective dimensions of the urban space, and reacting fast and flexibly to the changing social dynamics in the city.

\section{Notes}

${ }^{1}$ Lluís Bonet and Emmanuel Négrier, 'The Ends(s) of National Cultures? Cultural Policy in the Face of Diversity,' International Journal of Cultural Policy 17.5 (2011): 574-589.

${ }^{2}$ See e.g., Hans Erik Näss, 'The Ambiguities of Intercultural Dialogue: Critical Perspectives on the European Union's New Agenda for Culture,' Journal of Intercultural Communication 23 (2010).

${ }^{3}$ Kaarin Taipale, Cities for Sale. How Economic Globalization Transforms the Local Public Sphere (Espoo: Helsinki University of Technology, 2009), 42.

${ }^{4}$ Robert Cowan, The Dictionary of Urbanism (Tisbury: Streetwise Press, 2005).

${ }^{5}$ Graeme L. Evans, 'Measure for Measure: Evaluating the Evidence of Culture's Contribution to Regeneration,' Urban Studies 42.5-6 (2005): 1-25.

${ }^{6}$ See. e.g., Teodoro Luque-Martinez, Salvador Del Barrio-García, José Ángel Ibáñes-Zapata and Migual Ángel Rodriguez-Molina, 'Modeling a City's Image: the Case of Granada,' Cities 24.5 (2007): 335-352.

7 Jana Temelová, 'Urban Revitalization in Central and Inner Parts of (Postsocialist) Cities: Conditions and Consequences', in Regenerating Urban Core, ed. Tuomas Ilmavirta (Espoo: Helsinki University of Technology, 2009), 15.

${ }^{8}$ Ronan Paddison, 'City Marketing, Image Reconstruction and Urban Regeneration', Urban Studies 30.2 (1993): 339-350.

${ }^{9}$ Graeme L. Evans, 'Hard-Branding the Cultural City: From Prado to Prada,' International Journal of Urban and Regional Research 27.2 (2003): 417-440; Evans, 'Measure for Measure,' 1-25. 
${ }^{10}$ Kelly Chan, 'Pop-up Populism: How the Temporary Architecture Craze is Changing Our Relationship to the Built Environment,' Artinfo 8 May (2012).

11 Susanne Lacy, 'Introduction,' in Mapping the Terrain. New Genre Public Art, ed. Suzanne Lacy (Seattle: Bay Press, 1995), 19-47.

${ }^{12}$ Nishat Awan, Tatjana Schneider and Jeremy Till, Spatial Agency. Other Ways of Doing Architecture (London: Routledge, 2011).

${ }^{13}$ E.g., The Flying Grass Carpet, a project by Dutch HUNK-Design and ID-Eddy, which consists of a combination of several artificial grasses with different characteristics and colours woven together to resemble a huge Persian carpet, visited in 2010 three ECOCs: Pécs (Hungary), Essen (Germany), and Istanbul (Turkey). The Colourscape, a project by English Eye Music Trust comprising a huge walk-in network of interconnected chambers that bend the colours of light, visited Turku in August 2011.

${ }^{14}$ Nigel Taylor, Urban Planning Theory Since 1945 (London: Sage, 1998).

${ }^{15}$ Sonia A. Hirt, 'Towards Postmodern Urbanism? Evolution of Planning in Cleveland, Ohio,' Journal of Planning Education and Research 25.1 (2005), 29.

${ }^{16}$ Tigran Haas, ed., New Urbanism \& Beyond. Designing Cities for the Future (New York: Rizzoli, 2008).

${ }^{17}$ E.g., Heiko Schmid, Economy of Fascination. Dubai and Las Vegas as Themed Urban Landscapes (Berlin: Gebrüder Borntraeger, 2009).

${ }^{18}$ Doreen Jakob, 'The Eventification of Place: Urban Development and Experience Consumption in Berlin and New York City,' European Urban and Regional Studies 20:4 (2013), 447-459.

${ }^{19}$ Anne-Marie d'Hauteserre, 'Val d'Europe: A Pioneering Turn to "Experience" Planning?’ European Urban and Regional Studies, 20.4 (2013), 435-446.

20 Ibid.

${ }^{21}$ Tim Hall, 'Public Art, Civic Identity and the New Birmingham', in Remaking Birmingham: The Visual Culture of Urban Regeneration, ed. Liam Kennedy (London: Routledge, 2004), 71; Beatriz García, 'Cultural Policy and Urban Regeneration in Western European Cities: Lesson from Experience, Prospects for the Future,' Local Economy 19.4 (2004): 312-326; Evans, 'Measure for Measure,' $1-25$.

\section{Bibliography}

Awan, Nishat, Tatjana Schneider and Jeremy Till. Spatial Agency. Other Ways of Doing Architecture. London and New York: Routledge, 2011.

Bonet, Lluís and Emmanuel Négrier. 'The Ends(s) of National Cultures? Cultural Policy in the Face of Diversity.' International Journal of Cultural Policy 17.5 (2011): 574-589. 
Chan, Kelly. 'Pop-up Populism: How the Temporary Architecture Craze is Changing Our Relationship to the Built Environment.' Artinfo 8 May (2012). Viewed 15 June 2013. http://www.artinfo.com.

Cowan, Robert. The Dictionary of Urbanism. Tisbury: Streetwise Press, 2005.

Evans Graeme L. 'Hard-Branding the Cultural City: From Prado to Prada.' International Journal of Urban and Regional Research 27.2 (2003): 417-440.

'Measure for Measure: Evaluating the Evidence of Culture's Contribution to Regeneration.' Urban Studies 42.5-6 (2005): 1-25.

García, Beatriz. 'Cultural Policy and Urban Regeneration in Western European Cities: Lesson from Experience, Prospects for the Future.' Local Economy 19.4 (2004): 312-326.

Haas, Tigran, ed. New Urbanism \& Beyond. Designing Cities for the Future. New York: Rizzoli, 2008.

Hall, Tim. 'Public Art, Civic Identity and the New Birmingham'. Remaking Birmingham: The Visual Culture of Urban Regeneration, edited by Liam Kennedy, 63-71. London: Routledge, 2004.

d'Hauteserre, Anne-Marie. 'Val d'Europe: A Pioneering Turn to 'Experience' Planning?' European Urban and Regional Studies 20.4 (2013), 435-446.

Hirt, Sonia A. 'Towards Postmodern Urbanism? Evolution of Planning in Cleveland, Ohio.' Journal of Planning Education and Research 25.1 (2005): 2742.

Jakob, Doreen. 'The Eventification of Place: Urban Development and Experience Consumption in Berlin and New York City.' European Urban and Regional Studies 20:4 (2013), 447-459.

Lacy, Susanne. 'Introduction'. Mapping the Terrain. New Genre Public Art, edited by Suzanne Lacy, 19-47. Seattle: Bay Press, 1995.

Luque-Martinez, Teodoro, Salvador Del Barrio-García, José Ángel Ibáñes-Zapata and Migual Ángel Rodriguez-Molina. 'Modeling a City's Image: the Case of Granada.’ Cities 24.5 (2007): 335-352. 
Näss, Hans Erik. 'The Ambiguities of Intercultural Dialogue: Critical Perspectives on the European Union's New Agenda for Culture.' Journal of Intercultural Communication 23 (2010). Viewed 18 September 2013. http://www.immi.se/intercultural/.

Paddison, Ronan. 'City Marketing, Image Reconstruction and Urban Regeneration.’ Urban Studies 30.2 (1993): 339-350.

Schmid, Heiko. Economy of Fascination. Dubai and Las Vegas as Themed Urban Landscapes. Berlin: Gebrüder Borntraeger, 2009.

Taipale, Kaarin. Cities for Sale. How Economic Globalization Transforms the Local Public Sphere. Centre for Urban and Regional Studies Publications. Studies in Architecture A 36. Espoo: Helsinki University of Technology, 2009.

Taylor, Nigel. Urban Planning Theory Since 1945. London: Sage, 1998.

Temelová, Jana. 'Urban Revitalization in Central and Inner Parts of (Post-socialist) Cities: Conditions and Consequences.' Regenerating Urban Core, edited by Tuomas Ilmavirta. Publications in the Center for Urban and Regional Studies C72, 12-25. Espoo: Helsinki University of Technology, 2009.

Tuuli Lähdesmäki, PhD, is a Senior Researcher at the Department of Art and Culture Studies, University of Jyväskylä, Finland. In her previous research project funded by the Academy of Finland, she has explored cultural politics, identitybuilding, and urban development in the European Capital of Culture initiative. 